\title{
Peran Mediasi Dalam Rekonsiliasi Rumah Tangga Dari Perspektif Gender
}

\author{
Sihabudin Mukhlis \\ Mahasiswa Program Doktor Hukum Islam UIN Sunan Gunung Djati Bandung \\ *Korespondensi: mukhlissihabudin@gmail.com
}

Info Artikel

Diterima : 1 Sep 2020 Direvisi : 14 Okt 2020 Disetujui : 28 Okt 2020 Diterbitkan : 7 Des 2020

DOI: https://doi.org/10.31599/krtha.v14i2.282

Keywords : Mediation, dispute, reconciliation

Abstract : Marriage is a contract (akad) between men and women with the purpose of worship and giving happiness to each other. It's form a tranquility household and a prosperous society. But, not a few of the married couples who have problems in their household. The purpose of this Paper is to know how far is mediation become a part of the improvement to solve a conflict in houshold. The method that used is desrciptive analysis with a normative juridical approach. The results showed that mediation in religious courts was less effective. Because someone who was already there, tended to expect a separation. As an effort to prevent and repair from a houshold conflict. BP4 (Advisory Board, Fostering and Preservation of Marriage) serves to be the solution for a household confict that impact on divorce. The mediation process provides a facilities for both sides to solve the problem .The concept of gender becomes an alternative to build a family. Because knowledge and mental maturity become the key to being able to synergize and help each other in to build a home.

Kata kunci : Mediasi, perselisihan, Rekonsiliasi

Abstrak : Perkawinan merupakan akad antara laki-laki dan perempuan dengan tujuan ibadah dan saling memberikan kebahagiaan satu sama lain, sehingga membentuk sebuah rumah tangga yang sakinah serta masyarakat yang sejahtera. Namun tidak sedikit dari pasangan suami istri yang sudah terikat dalam ikatan rumah tangga, mengalami permasalahan dalam mengarungi bahtera rumah tangga. Tujuan dari makalah ini untuk mengatahui sejauh mana mediasi menjadi bagian dari perbaikan dari rumah tangga yang sedang mengalami perselisihan. Metode yang digunakan adalah metode deskriptif analisis dengan pendekatan yuridis normatif. Hasil kajian menunjukan bahwa mediasi yang hadir di pengadilan agama kurang efektif, karena seorang yang sudah hadir di Pengadilan Agama cenderung mengharapkan perpisahan. Sebagai upaya pencegahan dan perbaikan dari suami istri yang berselisih, BP4 (Badan Penasihatan, Pembinaan dan Pelestarian Perkawinan) berperan untuk menjadi solusi sebelum terjadinya perselisihan yang berdampak kepada perceraian. Proses mediasi memberikan sarana untuk sama-sama menyelesaikan permasalahan dengan partisipasi antara para pihak. konsep gender mendorong dalam membangun keluarga, Ilmu dan kematangan mental menjadi kunci agar mampu bersinergi dan saling membantu dalam proses membangun rumah. 


\section{PENDAHULUAN}

Perkawinan menjadi sebuah tujuan dari setiap laki-laki dan perempuan yang menghendaki untuk menempuh kehidupan baru, dalam menyatukan visi dan misi membangun keluarga bahagia dunia dan akhirat. Perkawinan merupakan sebuah syariat yang dianjurkan oleh agama, guna memberikan kehormatan bagi insan yang memilih ibadah untuk menyalurkan hasrat yang ada dalam diri setiap manusia. Hal ini sejalan dengan ketentuan yang ada dalam Undang-Undang Nomor 1 Tahun 1994 tentang Perkawinan (selanjutnya di sebut dengan UU Perkawinan) ${ }^{1}$ :

"Perkawinan adalah ikatan lahir batin antara seorang pria dan seorang wanita sebagai suami istri dengan tujuan membentuk keluarga atau rumah tangga yang Bahagia dan kekal berdasarkan Ketuhanan Yang Maha Esa.”

Dalam hukum islam yang terangkum dalam Kompilasi Hukum Islam (selanjutnya di sebut dengan KHI) perkawinan merupakan mitssaqon gholidzon atau sebuah akad yang kuat untuk mentaati perintah Allah dan menjadi ibadah ketika menjalaninya ${ }^{2}$. Secara detail bahkan islam menjelaskan tujuan pernikahan adalah mencapai keluarga yang sakinah, mawaddah dan rahmah, sebagaimana yang dijelaskan dalam Al-Qur'an:

Artinya : "Dan diantara tanda-tanda kebesaran-Nya ialah Dia menciptakan pasanganpasangan untukmu dari jenismu sendiri, agar kamu cenderung dan merasa tenteram kepadanya, dan Dia menjadikan di antaramu rasa kasih dan sayang. Sunggub, pada yang demikian itu benarbenar terdapat tanda-tanda kebesaran Allah bagi kaum yang berfikir". (Q.S Ar-Rum : 21)

Perkawinan menyatukan dua pandangan insan yang berbeda, lebih dalam lagi menyatukan dua lingkungan keluarga yang berbeda. Lingkungan keluarga suami yang berlatarbelakang dan pola pendidikan yang ada, tentunya berbeda dengan pola pendidikan dan latar belakang dari keluarga istri. Jika perbedaan yang dimiliki disatukan dengan dasar kebijaksanaan dan berlandaskan ibadah maka akan hadir sebuah ketentraman dan kasih sayang dalam sebuah rumah tangga. Jika di pandang melalui Metode mubadalah, maknanya laki-laki mendapatkan ketentraman dari istrinya dan istri berhak untuk mendapatkan ketentraman dari suaminya, baik itu dari aspek Spiritual, psikologi, ekonomi, hubungan sosial atau personal. ${ }^{3}$

Demi tercapainya tujuan dari sebuah perkawinan, maka harus ada saling kerjasama, saling pengertian dan memahami terhadap kepentingan suami dan istri, menerima

\footnotetext{
${ }^{1}$ Republik Indonesia, Undang-Undang Nomor 1 Tabun 1974 Tentang Perkawinan, Pasal 1.

2 Indonesia, Kompilasi Hukum Islam Pasal 2.

${ }^{3}$ Faqihuddin Abdul Kodir, Qira'ah Mubadalah: Tafsir Progresif Untuk Keadilan Gender Dalam Islam (Yogyakarta: Ircisod, 2019), hlm. 336
} 
kelebihan dan kekurangan dari keduanya, terkhusus dari sisi hak dan kewajiban antara seorang suami dan istri dalam membangun keluarga.

Pengaturan hak dan kewajiban antara suami dan istri termaktub dalam KHI Pasal 77, yang menjelaskan ketetentuan ${ }^{4}$ :

(1) Suami isteri memikul kewjiban yang luhur untuk menegakkan rumah tangga yang sakinah, mawaddah dan rahmah yang menjadi sendi dasar dan susunan masyarakat.

(2) Suami isteri wajib saling cinta mencintai, hormat menghormati, setia dan memberi bantuan lahir bathin yang satui kepada yang lain;

(3) Suami isteri memikul kewajiban untuk mengasuh dan memelihara anak-anak mereka, baik mengenai pertumbuhan jasmani, rohani maupun kecerdasannya dan pendidikan agamanya;

(4) Suami isteri wajib memelihara kehormatannya.

Seiring berjalannya waktu dalam membangun rumah tangga, tidak sedikit kita temukan antara suami dan istri mengalami pertengkaran dalam proses perkawinan, mengeluh dan mengadukan masalahnya kepada orang lain atau keluarga, dikarenakan faktor ekonomi, kesalahpahaman, berbeda pandangan, adanya hak dan kewajiban yang tidak terpenuhi atau ada faktor lain yang membuat keduanya berselisih. Hal tersebut membuka peluang antara keduanya terjadi perpisahan (putusnya perkawinan).

Disebabkan pertengkaran terus menerus yang terjadi antara suami istri, sehingga jalur litigasi di anggap menjadi solusi untuk penyelesaian masalah, kontruksi pemikiran masyarakat menilai bahwa ketika perkara yang sudah masuk Pengadilan Agama, maka berujung dengan perceraian. Padahal tidak demikian, Konsep penyelesaian sengketa di pengadilan menawarkan 2 cara berdasarkan Al-Quran dan Hadist untuk menyelesaikan perselisihan, diantaranya: (1) pembuktian fakta hukum (adjudikasi) dan (2) penyelesaian sengketa melalui perdamaian $(\text { islab })^{5}$.

Syariat islam tidak menyukai sebuah perceraian, namun juga tidak melarang. Islam memberikan jawaban ketika ada diantara pasangan suami istri yang memiliki masalah atau syiqoq (perselisihan / persengketaan antara suami dan istri) maka di kirimkanlah seorang hakam, sebagaimana disampaikan dalam Firman-Nya:

"Dan jïka kamu khawatirkan ada persengketaan antara keduanya, maka kirimlah seorang hakam dari keluarga laki-laki dan seorang hakam dari keluarga perempuan. Jika kedua orang

\footnotetext{
${ }^{4}$ Ibid, Pasal 77 ayat (1),(2),(3)(,4).

${ }^{5}$ Syahrizal Abbas, Mediasi Dalam Perspektif Hu kum Svariah, Hukum Adat Dan Hukum Nasional (Jakarta: Fajar Interpratyama Offset, 2010), hlm. 157
} 
hakam itu bermaksud mengadakan perbaikan, niscaya Allah memberi taufik kepada suami-isteri itu. Sesunggubnya Allah Maba Mengetahui lagi Maha Mengenal”. (QS. An-Nisa [4] : 35)

Ayat di atas memberikan pemahaman bahwa seorang hakam bersungguh-sungguh menjadi penengah untuk bisa menyelesaikan permasalahan yang dihadapi oleh suami istri, guna melakukan perbaikan hubungan rumah tangga. Upaya perdamaian yang dilakukan melalui perundingan dalam hukum positif Indonesia biasa di kenal dengan mediasi. Pengertian mediasi disampaikan dalam PERMA No 1 Tahun 2016, mediasi merupakan cara penyelesaian sengketa melalui proses perundingan untuk memperoleh kesepakatan Para Pihak dengan dibantu oleh Mediator ${ }^{6}$.

Pengadilan Agama merupakan lembaga kekuasaan kehakiman yang memeriksa, memutus dan menyelesaikan setiap perkara di tinggat pertama, bagi orang-orang islam. Kompetensi cakupannya meliputi: Perkawinan, waris, wasiat, hibah wakaf, infak, shodaqoh dan sengketa ekonomi syari'ah ${ }^{7}$. Dari beberapa jenis perkara di atas, perkara perkawinan khususnya perkara perceraian menduduki angka tertinggi di bandingkan perkara lain.

Mediasi diharapkan sebagai alternative penyelesaian sengketa atau perkara untuk mencapai kesepakatan dengan prinsip "win-win solution", jika hal ini berhasil dilakukan dengan baik maka tidak ada pihak yang kalah atau menang seperti dalam proses peradilan pada umumnya.

Kontruksi rumah tangga yang di bangun oleh suami istri, harus memiliki sebuah visi yang jelas dan pilar-pilar yang kokoh dalam menjalankan roda rumah tangga. Dalam konsep qiroah mubadalah dijelaskan pilar-pilar untuk menguatkan kebaikan dalam sebuah keluarga, diantaranya: pertama, mengingatkan tujuan rumah tangga sebagai perjanjian yang kuat atau kesapakatan antara kedua belah pihak untuk komitmen bersama. Kedua, relasi dalam sebuah pernikahan adalah berpasangan, sehingga harus saling melengkapi dan menerima kekurangan. Ketiga, sikap yang harus di selalu di timbulkan untuk memberikan yang terbaik terhadapa pasangan. Keempat, memberikan sikap dan perilaku untuk senantiasa bermusyawarah dalam memutuskaan sesuatu yang terkait rumah tangga. Kelima, senantiasa saling merasa nyaman dan memberi kenyamanan terhadap pasangan ${ }^{8}$.

Adapun dasar hukum mediasi jika di lihat dari historis yuridis di lembaga peradilan sudah sejak lama diberlakukan penyelesaian sengketa melalui upaya damai atau biasa di

\footnotetext{
${ }^{6}$ Pasal 1

${ }^{7}$ Undang-Undang No 3 Tahun 2006 Pasal 49

${ }^{8}$ Faqihuddin Abdul Kodir, Qira'ah Mubadalah: Tafsir Progresif Untuk Keadilan Gender Dalam Islam (Yogyakarta: Ircisod, 2019), hlm.343-355
} 
sebut dengan istilah dading yang telah di atur dalam pasal $130 \mathrm{HIR} /$ Pasal $154 \mathrm{RBg}$ dan UU No. 1 tahun 1974 Pasal 39, KHI Pasal 115, 143 (1-2), 144, PERMA No 1 Tahun 2008 dan PERMA No 1 Tahun 2016 tentang prosedur mediasi di pengadilan.

Berdasarkan uraian diatas, penulis merumuskan beberapa permasalahan dalam artikel ini, yakni sebagai berikut : Pertama, bagaimana peran mediasi dalam penyelesaian permasalahan rumah tangga? Kedua, bagaimana Mediasi dari perspektif Gender?

\section{PEMBAHASAN}

\section{A. Mediasi di Indonesia}

Kata mediasi berasal dari bahasa inggris "mediation", yang memiliki arti cara penyelesaian sengketa dengan melibatkan Pihak ketiga untuk menengahi menyelesaikan sengketa ${ }^{9}$. Pengertian mediasi dari segi etimologi berasal dari bahasa latin yakni mediare yang berarti berada di tengah. Dijelaskan oleh syahrizal abbas dalam bukunya, hal ini memberikan makna bahwa seorang mediator menjalankan tugas sebagai pihak ketiga untuk membantu menyelesaikan sengketa antara pihak dengan mengkondisikan diri untuk netral, tidak memihak kepada salah satu pihak. ${ }^{10}$ Seorang mediator harus mampu menjaga kepentingan para pihak yang bersengketa secara adil, sehingga menimbulkan rasa kepercayaan di antara para pihak.

Mediasi adalah suatu proses penyelesaian sengketa antara dua pihak atau lebih melalui perundingan atau cara mufakat dengan bantuan pihak netral yang tidak memiliki kewenangan memutus. Pendekatan konsensus atau mufakat dalam proses mediasi mengandung pengertian, bahwa segala sesuatu yang dihasilkan dalam proses mediasi harus merupakan hasil kesepakatan atau persetujuan para pihak ${ }^{11}$. Sedangkan dalam kamus besar bahasa Indonesia, kata mediasi memiliki arti sebagai pengikutsertaan pihak ketiga, dalam penyelesaian suatu perselisihan sebagai nasihat ${ }^{12}$.

Wahbah Az-Zuhaili berpendapat bahwa mediasi merupakan kesepakatan perdamaian para pihak yang bersangkutan, menunjukan pengertian lebih luas tentang mediasi yang

\footnotetext{
${ }_{9}$ Rachmadi Usman, Pilihan Penyelesaian Sengketa Diluar Pengadilan, (Citra Aditya Bakti : Bandung, 2003), hlm. 79

${ }_{10}$ Syahrizal Abbas, Mediasi Dalam Hukum Syariah, Hukum Adat, dan Hukum Nasional, (Jakarta: Kencana, 2011), hlm.2

11 Takdir Rahmadi, Mediasi Penyelesaian Sengketa Melalui Pendekatan Mufakat, (Jakarta: Rajawali Pers, 2010), hlm. 12

12 Tim Penyusun Kamus Pusat Pembinaan Dan Pengembangan Bahasa, Kamus Besar Bahasa Indonesia, (Jakarta: Departemen Pendidikan dan Kebudayaan, 1988), hlm. 569
} 
mengarahkan kepada tujuan mediasi itu sendiri ${ }^{13}$. Mediasi bisa dikatakan proses damai antara pihak yang bersengketa, yang mana diserahkan kepada mediator (dilakukan pertemuan antara pihak dan mediator) untuk mendapatkan hasil akhir yang adil dengan biaya yang tidak besar dan hasilnya efektif karena di terima oleh kedua belah pihak yang bersengketa dengan sukarela. Islam mengajarkan untuk dianjurkannya mengirimkan seorang hakam, untuk menyelesaikan persengketaan, sebagaimana di sampaikan dalam firman-Nya:

Artinya: "Dan jika kamu khawatirkan ada persengketaan antara keduanya, maka kirimlah seorang hakam dari keluarga laki-laki dan seorang hakam dari keluarga perempuan. Jika kedua orang hakam itu bermaksud mengadakan perbaikan, niscaya Allah memberi taufik kepada suami-isteri itu. Sesungguhnya Allah Maha Mengetahui lagi Maha Mengenal.” (QS. Annisa [4]: 35)

Ayat di atas memberikan pemahaman bahwa seorang hakam bersungguh-sungguh menjadi penengah untuk bisa menyelesaikan permasalahan yang dihadapi oleh suami istri, guna melakukan perbaikan hubungan rumah tangga. Upaya perdamaian yang dilakukan melalui perundingan dalam hukum positif Indonesia biasa di kenal dengan mediasi.

Landasan hukum mediasi di atur dalam pasal $130 \mathrm{HIR} /$ Pasal $154 \mathrm{RBg}$ dan UU No. 1 tahun 1974 Pasal 39, KHI Pasal 115, 143 (1-2), 144, PERMA No 1 Tahun 2016 tentang prosedur mediasi di pengadilan. Dalam pasal 1 ayat (1) Perma No 1 Tahun 2016 di sebutkan bahwa Mediasi merupakan cara penyelesaian sengketa melalui proses perundingan untuk memperoleh kesepakatan Para Pihak dengan dibantu oleh Mediator.

Landasan Yuridis Mediasi di luar pengadilan diatur dalam KUHPerdata Pasal 1851 yakni 'Perdamaian adalah suatu persetujuan dimana kedua belah pihak dengan menyerahkan, menjanjikan atau menahan suatu barang, mengakhiri suatu perkara yang sedang diperiksa dipengadilan atau mencegah timbulnya suatu perkara”. Pengaturan mediasi atau alternatif penyelesaian sengketa diluar pengadilan disebutkan dalam UndangUndang Nomor 30 Tahun 1999 tentang Arbitrase dan Alternatif Penyelesaian Sengketa yang dinyatakan dalam Pasal 1 angka 10 ialah :

"Alternatif penyelesaian sengketa adalah lembaga penyelesaian sengketa atau beda pendapat melalui prosedur yang disepakati para pibak, yakni penyelesaian sengketa di luar pengadilan dengan cara konsultasi, negosiasi, mediasi, konsiliasi atau penilaian abli"

Proses mediasi awalnya dilakukan di luar institusi pengadilan (non-litigasi) bagi para

13 Wahbah Zuhaili, Fiqib Imam Syafi'T Mengupas Masalab Fiqhiyah Berdasarkan Al-Qur'an dan Hadits 2, alih bahasa Muhammad Afifi dan Abdul Hafiz, (Jakarta: Almahira, 2010), hlm. 131. 
pihak yang berselisih, namun dengan perkembangan zaman dan perubahan perilaku, mediasi di jadikan proses beracara di pengadilan yang tidak terpisahkan dengan institusi pengadilan (litigasi). Proses mediasi menjadi sebuah kewajiban yang harus di lakukan oleh hakim sebelum melakukan proses beracara selanjutnya.

Jika melihat PERMA No.1 Tahun 2016 ada beberapa kelebihan mengapa digunakan mediasi di pengadilan, pertama, proses mediasi dipandang lebih cepat dalam menyelesaikan sengketa dan murah di bandingkan dengan proses persidangan. Kedua, menjalankan mediasi bisa menjadi akses lebih luas untuk para pihak memporoleh keadilan. Ketiga, proses mediasi tertutup dan rahasia. Keempat, memperkuat dan mengoptimalkan fungsi lembaga peradilan dalam penyelesaian sengketa.

Semua sengketa yang masuk ke pengadilan agama diwajibkan melakukan upaya penyelesaian dengan mediasi, hal ini menjadi proses yang harus di tempuh oleh hakim untuk menyelesaikan perkara baik itu di awal atau di tengah-tengah pemeriksaan perkara. Adapun tujuan dari mediasi dalam perkara perceraian meliputi: pertama, agar suami istri menjadi rukun kembali berkeluarga dan tidak melanjutkan perceraian; kedua, dengan sukarela suami istri melanjutkan hubungan rumah tangga dengan memenuhi hak dan kewajiban; ketiga, jika terjadi perdamaian maka perkara perceraian dicabut.

Lembaga peradilan baik Peradilan Agama dan Peradilan Negeri telah menyiapkan mediator yang akan membantu proses mediasi. Dalam PERMA No.1 Tahun 2016 pasal 13, yang berhak untuk menjadi seorang mediator yakni seorang hakim atau mediator yang di sahkan oleh mahkamah agung memiliki sertifikat sebagai mediator. Sehingga nantinya para pihak berhak untuk bersepakat memilih mediator hakim atau non-hakim yang akan mmbantu proses mediasi di pengadilan tersebut.

Mediator yang di tunjuk dalam mediasi tersebut harus berpedoman kepada PERMA tentang mediasi, agar terciptanya perdamaian antara kedua belah pihak dan untuk memberikan kepastian hukum dan ketertiban dalam proses penyelesaian sengketa.

Dari hal tersebut menunjukan bahwa mediasi mengarahkan untuk memberikan keputusan yang memenangkan kedua belah pihak (win-win solution) dan tidak ada pihak yang merasa dirugikan. Dalam PERMA No.1 Tahun 2016, disampaikan tahapan proses mediasi kepada dua hal yakni, pramediasi dan mediasi. Pramediasi dilakukan dengan cara pemanggilan para pihak, hakim menjelaskan prosedur mediasi, pengertian dan manfaat mediasi, menyerahkan formulir penjelasan mediasi yang memuat para pihak persedia 
beritikad baik dalam mediasi ${ }^{14}$. Jika selesai pramediasi maka berlanjut kepada tahapan mediasi, yakni seperti sambutan pendahuluan dari mediator, paparan dari kedua belah pihak, identifikasi masalah keduanya, negosiasi, menawarkan opsi-opsi, menemukan kesepahaman dan merumuskan kesepakatan dan ditutup dengan penutupan proses mediasi oleh mediator ${ }^{15}$.

Proses mediasi berlangsung paling lama 30 (tiga puluh) hari terhitung sejak penetapan perintah melakukan Mediasi. Jika waktu tersebut di rasa kurang dalam proses mediasi maka Atas dasar kesepakatan Para Pihak, jangka waktu Mediasi dapat diperpanjang paling lama 30 (tiga puluh) hari terhitung sejak berakhir jangka waktu yang di tentukan di awal. Mediator atas permintaan para pihak mengajukan perpanjangan waktu mediasi kepada hakim pemeriksa perkara dengan menyempaikan alasannya ${ }^{16}$.

\section{B. Mediasi sebagai Rekonsiliasi Rumah Tangga}

Perselisihan yang terjadi dalam rumah tangga dalam islam disebut juga dengan istilah syiqaq. Arti kata syiqaq ialah retak, yang berarti retaknya hubungan dalam perkawinan ${ }^{17}$. Hal tersebut di akibatkan oleh beberapa faktor, baik itu masalah ekonomi, kedewasaan dan keilmuan yang di miliki oleh suami atau istri.

Sementara menurut Abdul Rahman Ghozali, syiqaq adalah krisis memuncak yang terjadi antara suami dan istri sedemikian rupa, sehingga antara suami dan istri pertentangan pendapat dan pertengkaran, menjadi dua pihak yang tidak mungkin dipertemukan dan kedua belah pihak tidak dapat mengatasinya ${ }^{18}$. Jika sudah terjadi hal demikian maka pihak orang ketiga yakni hakam sangat dibutuhkan untuk menengahi perselisihan tersebut, sehingga bisa diberikan jalan keluar untuk pasangan yang berselisih dengan cara mediasi.

Keilmuan dan kedewasaan seorang pasangan suami istri menjadi hal yang penting, sehingga mencegah terjadinya sebuah permasalahan yang tidak berbuah solusi untuk kebaikan rumah tangga. Khususnya dalam ilmu pernikahan (Munakahat), sebagai bekal untuk saling mengetahui hak dan kewajiban antara suami istri, menyeimbangkan antara

\footnotetext{
14 PERMA No.1 Tahun 2016 Pasal 17

15 Syahrizal Abbas, Mediasi Dalam Perspektif Hukum Svariah, Hukum Adat Dan Hukum Nasional, hlm. 44

16 PERMA No.1 Tahun 2016 pasal 24

${ }^{17}$ Ahmad Azhar Basyir, Hukum Perkawinan Islam, cet.ke-9 (Yogyakarta: UII Press, 1999), hlm. 88

18 Abdul Rahman Ghozali, Fikih Munakahat, Edisi-1 (Jakarta: Kencana Prenaada Media Group, 2013), hlm. 241
} 
hubungan dengan sesama dan hubungan dengan sang Maha Pencipta (Allah SWT) dalam Aspek spiritual.

Perspektif masyarakat saat ini, ketika mengalami perselisihan dalam rumah tangga yang tak kunjung selesai, maka berpikir untuk datang ke pengadilan agama dengan harapan mendapatkan solusi yakni dengan perceraian. Padahal hal tersebut bukanlah solusi satusatunya, saat ini prosedur di pengadilan agama mengarahkan untuk menempuh penyelesaian dengan mediasi sebagai rangkaian proses di pengadilan agama.

Hal tersebut yang menjadi penyebab banyaknya terjadi sebuah perceraian di pengadilan agama, jika di ibaratkan dengan orang sakit yang di rujuk kerumah sakit, orang tersebut memang sudah memiliki penyakit komplikasi dan sakit berat, sehingga sedikit kemungkinan untuk bisa sembuh. Begitu juga dengan seorang pasangan suami istri di pengadilan agama, mereka datang ke Pengadian Agama dengan tujuan untuk mengurus perceraian $^{19}$.

Jika kita melihat kasus yang terjadi saat ini, berdasarkan info yang didapatkan bahwa kasus yang masuk Pengadilan Agama Ciamis di Tahun 2019 ada sekitar 5961 Perkara (semua jenis Perkara), dan perkara yang di mediasi 171 dengan tingkat keberhasilan hanya 2 perkara (Perkara Perceraian) saja ${ }^{20}$. Ini menunjukan bahwa peran mediasi belum bisa menjadi upaya untuk memberikan perdamaian antara para pihak, dikarenakan para pihak (khususnya kasus Cerai/talak) menginginkan untuk berpisah ketika datang ke Pengadilan Agama.

\begin{tabular}{|c|c|c|c|c|c|c|c|}
\hline \multirow[t]{2}{*}{ No } & \multirow[t]{2}{*}{ Bulan } & \multirow{2}{*}{$\begin{array}{l}\text { Perkara } \\
\text { yang } \\
\text { diterim } \\
\text { a bulan } \\
\text { ini }\end{array}$} & \multirow{2}{*}{$\begin{array}{c}\text { Jumlah } \\
\text { perkara } \\
\text { yang } \\
\text { tidak bisa } \\
\text { di mediasi }\end{array}$} & \multirow{2}{*}{$\begin{array}{l}\text { Jumlah } \\
\text { perkara } \\
\text { yang di } \\
\text { mediasi }\end{array}$} & \multicolumn{3}{|c|}{$\begin{array}{c}\text { Laporan penyelesaian } \\
\text { mediasi }\end{array}$} \\
\hline & & & & & $\begin{array}{l}\text { Tidak } \\
\text { berhasil }\end{array}$ & $\begin{array}{c}\text { Berhasi } \\
1\end{array}$ & Gagal \\
\hline 1 & Januari & 674 & 1057 & 8 & 7 & 0 & 0 \\
\hline 2 & Februari & 464 & 1205 & 16 & 16 & 0 & 1 \\
\hline 3 & Maret & 480 & 1167 & 12 & 12 & 0 & 0 \\
\hline 4 & April & 428 & 1138 & 13 & 12 & 0 & 1 \\
\hline 5 & Mei & 339 & 931 & 14 & 13 & 0 & 1 \\
\hline 6 & Juni & 385 & 852 & 7 & 6 & 0 & 0 \\
\hline 7 & Juli & 632 & 1132 & 13 & 13 & 0 & 0 \\
\hline 8 & Agustus & 483 & 986 & 27 & 26 & 0 & 1 \\
\hline 9 & $\begin{array}{l}\text { Septermbe } \\
\mathrm{r}\end{array}$ & 509 & 987 & 17 & 14 & 1 & 1 \\
\hline
\end{tabular}

${ }^{19}$ Wawancara melalui whats-up dengan ketua pengadilan ciamis (bapak Anang Permana), 2 Juni 2020

${ }^{20}$ Informasi di dapatkan dari Ketua Pengadilan Agama Ciamis (Bapak Anang Permana). 


\begin{tabular}{|c|c|c|c|c|c|c|}
\hline 10 Oktober & 572 & 1032 & 21 & 19 & 1 & 1 \\
\hline November & 574 & 1008 & 10 & 10 & 0 & 0 \\
\hline 12 Desember & 421 & 844 & 13 & 13 & 0 & 0 \\
\hline Jumlah & 5961 & 12339 & 171 & 161 & 2 & 6 \\
\hline
\end{tabular}

Tabel 1. Jumlah Perkara Laporan Mediasi Pengadilan Agama Ciamis

Tindakan yang ditempuh mediator harus sangat hati-hati, karena persoalan keluarga dianggap masalah yang sensitif dan membutuhkan konsentrasi penuh, demi untuk merekatkan hubungan emosional yang rapuh. Memahami situasi suami istri merupakan kewajiban mediator dalam rangka menciptakan damai dan rekonsiliasi dalam keluarga yang bersengketa. Dengan demikian, mediator dapat menciptakan situasi yang menyebabkan kedua pihak percaya dan tumbuh keinginan untuk bersatu kembali mempertahankan rumah tangga ${ }^{21}$.

Proses mediasi yang dilakukan di pengadilan agama untuk menjadi wasilah perdamaian antara para pihak yang berselisih memiliki kendala dari beberapa aspek, sehingga tujuan mediasi belum bisa terwujud untuk menjadi sebuah solusi dalam perbaikan antara para pihak, kendala tersebut diantaranya ${ }^{22}$ :

1. Aspek para pihak

Kegagalan mediasi dapat dilihat pula dari aspek para pihak yang berperkara. Kedudukan para pihak dalam proses mediasi sangat penting. Keberhasilan dan kegagalan proses mediasi terletak pula pada kemauan, dan itikad baik para pihak di dalam mewujudkan keberhasilan mediasi.

Para pihak yang datang ke peradilan pada dasarnya telah melakukan perundingan terlebih dahulu. Proses sengketa terjadi karena tidak adanya titik temu antara pihak-pihak yang bersengketa. Para pihak yang bersengketa menginginkan agar kepentingannya tercapai, hakhaknya dipenuhi, kekuasannya diperlihatkan dan dipertahankan. Seseorang yang mengajukan tuntutannya ke pengadilan, berarti orang tersebut berkeinginan agar tuntutannya diperiksa dan diputus oleh pengadilan. Mereka menghendaki adanya suatu proses hukum untuk membuktikan dalil-dalil sebagaimana yang dimuat dalam tuntutan sehingga ketika kepada mereka agar menempuh proses mediasi, mereka tidak menunjukkan keseriusan dalam proses mediasi yang

21 Majalah Hukum Varia Peradilan Tahun XXXI Nomor 360 November 2015, Ikatan Hakim Indonesia (IKAHI), Jakarta, 2015, hlm. 95-96.

${ }^{22}$ Ramdhani wahyu sururie, implementasi mediasi dalam system peradilan agama, jurnal wacana hukum islam dan kemanusiaan, no 2 (2012) : 156-157 
ditunjukkan dengan ketidakhadiran salah satu pihak secara inperson dalam proses mediasi.

Kegagalan proses mediasi yang disebabkan oleh para pihak dapat diidentifikasi oleh adanya persepsi para pihak tentang mediasi, kebulatan tekad para pihak untuk bercerai sangat kuat karena kondisi rumah tangganya sudah berada diambang kehancuran, para pihak tertutup untuk mengutarakan masalahnya, proses perundingan untuk mencari titik temu sudah dilakukan berulang-ulang di luar pengadilan dengan kesimpulan bercerai dan rasa gengsi.

2. Aspek advokat

Para pihak yang diwakili oleh advokat biasanya tidak ikut serta dalam mengikuti proses mediasi yang diselenggarakan di pengadilan agama. Segala sesuatu yang terkait dengan penyelesaian sengketa baik pada saat pendaftaran gugatan maupun dalam hal penyelesaian mediasi sepenuhnya diserahkan kepada advokat.

Dengan demikian, mengingat advokat mewakili kepentingan kliennya, jika kliennya sudah berketetapan hati untuk bercerai, maka advokat akan mengikuti kehendak sang klien. Tetapi sebaliknya, jika kilennya mengharapkan ada upaya damai dengan salah satu pihak, biasanya mereka datang didampingi dengan advokatnya.

Kendala yang di hadapi diatas, bertambah juga dengan penumpukan perkara yang banyak di setiap pengadilan, sehingga hakim yang menjadi mediator terkadang sudah banyak menangani kasus sebelumnya, sehingga dalam proses mediasi belum begitu maksimal di tambah tidak ada iktikad baik dari para pihak.

Kontruksi rumah tangga yang di bangun oleh suami istri, harus memiliki sebuah visi yang jelas dan pilar-pilar yang kokoh dalam menjalankan roda rumah tangga. pilar-pilar untuk menguatkan kebaikan dalam sebuah keluarga, diantaranya: pertama, mengingatkan tujuan rumah tangga sebagai perjanjian yang kuat atau kesapakatan antara kedua belah pihak untuk komitmen bersama. Kedua, relasi dalam sebuah pernikahan adalah berpasangan, sehingga harus saling melengkapi dan menerima kekurangan. Ketiga, sikap yang harus di selalu di timbulkan untuk memberikan yang terbaik terhadapa pasangan. Keempat, memberikan sikap dan perilaku untuk senantiasa bermusyawarah dalam 
memutuskaan sesuatu yang terkait rumah tangga. Kelima, senantiasa saling merasa nyaman dan memberi kenyamanan terhadap pasangan ${ }^{23}$.

Tujuan dalam berumah tangga harus senantiasa digaungkan untuk menjadi sebuah pondasi keharmonisan antara seorang suami dan istri, hal ini menjadi faktor untuk adanya orang ketiga (hakam) atau juru damai dalam membantu membangun perspektif tujuan dari pernikahan ketika terjadi perselisihan. Faktor Keilmuan perkawinan yang harus dimiliki oleh setiap pasangan suami istri menjadi hal yang sangat diperlukan, dari mulai bagaiamana cara memuliakan pasangan, saling membantu, hak dan kewajiban, dan dari dimensi spiritual. Di Indonesia sudah ada BP4 (Badan Penasihatan, Pembinaan dan Pelestarian Perkawinan) yang sebagaimana di atur dalam Pasal 28 ayat (3) Peraturan Menteri Agama Nomor 3 Tahun 1975 Tentang Kewajiban-kewajiban Pegawai Nikah Dan Tata Kerja Pengadilan Agama dalam Melaksanakan Perundang-undangan Perkawinan Bagi Yang Beragama Islam menyatakan :

"Pengadilan Agama setelah mendapat penjelasan tentang maksud talak itu, berusaba mendamaikan kedua belah - pibak dan dapat meminta bantuan kepada Badan Penasehat Perkawinan dan Penyelesaian Perceraian (BP4) setempat, agar kepada suami - isteri dinasehati untuk, hidup rukun lagi dalam rumah tangga."

Banyaknya para pihak yang berperkara di Pengadilan Agama melakukan mediasi dalam proses perceraian tanpa mengetahui adanya keberadaan Badan Penasihatan, Pembinaan dan Pelestarian Perkawinan (BP4), sehingga fungsi dari BP4 tersebut kurang efektif. Peran BP4 dalam melakukan mediasi pada perkara perceraian sangat dibutuhkan bagi kedua belah pihak guna untuk menasehati serta membina para pihak agar mencapai rumah tangga yang rukun.

Peran dari BP4 (Badan Penasihatan, Pembinaan dan Pelestarian Perkawinan) inilah yang semestinya di perhatikan, sehingga proses mediasi yang terjadi di pengadilan agama tidak sampai kepada titik puncak untuk melakukan perceraian. Edukasi kepada masyarakat terhadap kepentingan ilmu pernikahan untuk membangun keluarga bisa dilakukan di BP4, bagitu juga ketika terjadi perselisiahn yang perlu dilakukan, maka masyarakat proaktif untuk bisa mencari solusi dari permasalahannya. Pada akhirnya tujuan dari pada mediasi untuk melakukan perdamaian (islah) mejadi sebuah konsep yang tertanam dari setiap keluarga, ketika terjadi sebuah perselisihan.

${ }^{23}$ Faqihuddin Abdul Kodir, Qira'ah Mubadalah: Tafsir Progresif Untuk Keadilan Gender Dalam Islam (Yogyakarta: Ircisod, 2019), hlm.343-355 


\section{Mediasi dari perspektif Gender}

Proses membangun rumah tangga hadir permasalahan antara suami dan istri, mengakibatkan sebuah perselisihan yang terus menerus (syiqaq) sehingga berujung pada pengadilan agama. PERMA No 1 Tahun 2016 dalam pasal 1 ayat (1) disebutkan bahwa Mediasi merupakan cara penyelesaian sengketa melalui proses perundingan untuk memperoleh kesepakatan Para Pihak dengan di bantu oleh Mediator. Mediasi yang saat ini di integrasikan ke dalam prosedur berperkara di Pengadilan.

Mediasi yang diterapkan dalam aturan PERMA No.1 Tahun 2016, mendukung untuk adanya keadilan gender, yakni memberikan kesamaan hak kepada pasangan suami istri untuk sama-sama partisipasi menyelesaikan permasalahan dengan beritikad baik, memilih mediator, para pihak diberikan kesempatan untuk menyampaikan permasalahan dan mengajukan usulan untuk perdamaian. Sehingga akan memberikan dua hasil yakni antara keberhasilan mediasi atau tidak berhasil mediasi. Hasil Mediasi memberikan proses yang terbaik untuk para pihak, karena tidak ada yang merasa dirugikan dan semuanya dianggap sama.

Pada dasarnya dalam islam tidak ada yang membedakan antara laki-laki dan perempuan, karena telah di jelaskan bahwa kedudukan manusia di hadapan Allah sama, hanya tingkat ketakwaan dan amal sholeh yang menjadi ukuranya. Potensi-potensi yang dimiliki laki-laki dan perempuan memiliki kelebihan masing-masing, sesuai dengan proses pembelajaran yang dilakukan antara keduanya. Sudut pandang patriarki dibanyaknya pemikiran masyarakat membuat

Praktik mediasi yang sudah menjadi ketentuan wajib dilakukan dalam proses berperkara di Pengadilan, terkhusus dalam perkara gugat cerai atau talak. Pasal 129 KHI menyebutkan ketika seorang suami ingin menjatuhkan talak kepada istrinya, maka suami harus mengajukan permohonan baik lisan atau tulisan kepada pengadilan agama yang mewilayahi tempat kediaman istri. Selanjutnya Pasal 132 KHI menerangkan ketika seorang istri hendak melakukan gugatan perceraian maka istri mengajukan gugatan ke Pengadilan Agama yang daerah hukumnya mewilayahi tempat tinggal penggugat (istri).

Aturan diatas menunjukan adanya bias gender yang ada, menunjukan bahwa ketidakmampuan perempuan untuk melakukan hal lebih, ketika sebuah keinginan untuk melakukan gugat cerai, dilakukan di tempat domisili istri, bukan di tempat suami. Beda halnya ketika suami ingin melakukan cerai talak, maka suami harus melakukan gugatan ke Pengadilan Agama di wilayah istri. Hal ini menunjukan seakan perempuan (istri) tidak 
mampu untuk melakukan hal yang dilakukan oleh laki-laki, padahal hal yang demikian termasuk kepada peran yang bisa dilakukan oleh seorang perempuan.

\section{KESIMPULAN}

Mediasi yang saat ini berjalan belum begitu efektif dikarenakan keterlambatan upaya perbaikan hubungan rumah tangga yang seharusnya di fungsikan sebelum di Pengadilan Agama, dengan mengfungsikan BP4 (Badan Penasihat, pembinaan, pelestarian perkawinan) untuk memberikan edukasi terkait ilmu pernikahan dan pembinaan rutin. Sehingga pengadilan agama tidak di jadikan akhir dari solusi untuk melakukan perceraian.

Proses mediasi sudah memberikan sarana penegakan keadilan gender dengan adanya kesamaan hak untuk sama-sama berpartisipasi dalam menyelesaikan pemasalahan dalam poses mediasi. Namun dalam proses beracara masih ada bias gender dengan memperlakukan perempuan sebagai pihak yang tidak mampu berupaya, dalam segi pengajuan gugatan di wilayah perempuan (istri).

\section{SARAN}

Pemerintah sebaiknya memberikan perhatian lebih terhadap BP4, baik itu untuk para mediator atau fasilitas yang ada, untuk menjadi pintu pembinaan bagi keluarga, sehingga mencegah dari terjadi perselisihan yang berujung kepada perceraian di pengadilan agama.

\section{DAFTAR PUSTAKA}

Abbas, Syahrizal, Mediasi Dalam Perspektif Hu kum Svariah, Hukum Adat Dan Hukum Nasional, Jakarta: Fajar Interpratyama Offset, 2010.

, Mediasi Dalam Hukum Syariah, Hukum Adat, dan Hukum Nasional, Jakarta: Kencana, 2011.

Basyir, Ahmad Azhar, Hukum Perkawinan Islam, cet.ke-9 (Yogyakarta: UII Press, 1999.

Ghozali, Abdul Rahman, Fikih Munakahat, Edisi-1,Jakarta: Kencana Prenaada Media Group, 2013.

Indonesia, Republik , Undang-Undang Nomor 1 Tahun 1974 Tentang Perkawinan, Pasal 1.

, Republik, Kompilasi Hukum Islam Pasal 2.

-, Republik, Undang-Undang No 3 Tahun 2006 Pasal 49

PERMA No.1 Tahun 2016 Pasal 17

PERMA No.1 Tahun 2016 pasal 24 
Kodir, Faqihuddin Abdul, Qira'ah Mubadalah: Tafsir Progresif Untuk Keadilan Gender Dalam Islam, Yogyakarta: Ircisod, 2019

Majalah Hukum Varia Peradilan Tahun XXXI Nomor 360 November 2015, Ikatan Hakim Indonesia (IKAHI), Jakarta, 2015

Rahmadi, Takdir , Mediasi Penyelesaian Sengketa Melalui Pendekatan Mufakat, Jakarta: Rajawali Pers, 2010

Sururie, Ramdhani wahyu, implementasi mediasi dalam system peradilan agama, jurnal wacana hukum islam dan kemanusiaan, no 2 (2012)

Usman, Rachmadi, Pilihan Penyelesaian Sengketa Diluar Pengadilan, Citra Aditya Bakti : Bandung, 2003

Tim Penyusun Kamus Pusat Pembinaan Dan Pengembangan Bahasa, Kamus Besar Bahasa Indonesia, Jakarta: Departemen Pendidikan dan Kebudayaan, 1988

Zuhaili, Wahbah, Fiqih Imam Syafi'I Mengupas Masalah Fiqhiyah Berdasarkan AlQur'an dan Hadits 2, alih bahasa Muhammad Afifi dan Abdul Hafiz, Jakarta: Almahira, 2010 